\title{
PTHLH Gene
}

National Cancer Institute

\section{Source}

National Cancer Institute. PTHLH Gene. NCI Thesaurus. Code C24698.

This gene is involved in the differentiation and proliferation of chondrocytes during endochondrial ossification. It also plays a role in lactation. 